\title{
Новые вызовы безопасности: введение
}

\section{Детлеф Пул}

Управление новых вызовов безопасности, Международный секретариат HATO

Ландшафт безопасности в начале 21 века является текучим и динамичным, характеризуется развитием технологий, систем вооружений и систем коммуникаций, а также сдвигами в международном политическом ландшафте и организационных структурах негосударственных акторов, составляющими серьезные и непосредственные угрозы для национальной и международной безопасности. В этой среде НАТО находится на перепутье. Его Стратегическая концепция, принятая в ноябре 2010 в Лиссабоне, отмечает начало его адаптации к этой новой реальности, отражающей среду безопасности с последствиями не только для НАТО и его партнеров - среду, в которой фундаментальные глобальные сдвиги продолжатся и в следующие годы: в глобальном распределении сил, в том числе и в ревизионистских действиях непосредственных соседей и фундаментальных вызовах к нашему международному порядку, основанному на правилах, создаваемых в основном радикальными исламистскими организациями и действующими в демографии; в экономике; в технологиях; в окружающей среде. Сталкиваясь с такими очень разными глобальными вызовами нашей безопасности, НАТО должно стремиться к сохранению своей сплоченности, должно развивать более широкое представление о трансатлантической безопасности и улучшать свою адекватность в противостоянии современным угрозам и вызовам.

Перед лицом нетрадиционных, в основном невоенных вызовов безопасности, которые по разному оказывают влияние на союзников, Аль- 
янсу нужно утвердить и усилить свое единство как внутри самой организации, так и со своими партнерами и странами за рамками партнерства. Необходимо разработать политику и развивать определенные деятельности, если они не хотят быть раздавленными этими новыми проблемами. Чтобы выполнить эту задачу, союзникам необходим новый и больший опыт в разрешении этих проблем, в рамках организации и вместе с партнерами. Им нужно повысить и поддерживать осведомленность о новых вызовах и более активно сотрудничать с внешними акторами. В этом плане, многое могут предложить нейтральные и неприсоединившиеся страны с их опытом в использовании мягкой силы.

С этой целью Консорциум Партнерства ради мира создал Рабочую группу по новопоявляющимся вызовам безопасности, которая будет заниматься некоторыми очень фундаментальными вопросами:

- Что конкретно следует понимать под названием «Назревающие проблемы безопасности», которыми занимается специальное управление Международного секретариата НАТО, созданное в 2010 году?

- Какую роль должны играть вооруженные силы в их разрешении?

- Какая организация необходима нам, чтобы встретить эти вызовы?

- Что может сделать Альянс и его партнеры в сотрудничестве с нейтральными и неприсоединившимися странами и другими акторами, чтобы помочь руководству этого процесса?

- Какое влияние оказывает коллективная борьба с этими проблемами на наше международное взаимодействие?

- Как нам нужно образовывать и обучать свой персонал и наших лидеров, чтобы они могли сотрудничать интеллигентным образом в более сложной и взаимосвязанной среде безопасности?

В итоге, нам необходимо думать, говорить, обсуждать коллективно новую среду безопасности, которая весьма отлична от той, к которой мы привыкли. Это верно для всех наших стран, для Альянса в качестве организации и для всего международного сообщества. Эта среда и дальше будет меняться неожиданным и необычным способом, и мы не знаем, что будет следующим. Для союзников и их партнеров критически важно найти совместимые, если не подобные или общие ответы на эти вызовы. Некоторые считают, что НАТО является полезной и доказавшей себя рамкой и инструментом для общего разрешения таких проблем нашей 
безопасности; другие предпочитают полагаться на национальные способности и двустороннее сотрудничество, возлагая на НАТО задачу резервного гаранта территориальной безопасности.

Рабочая группа по новым вызовам безопасности обсуждала многие из этих вопросов на шести проведенных до сих пор семинарах. Группа намеревается изучить и повысить осведомленность о новых технологиях и их влиянии на политику безопасности. Она также пытается стимулировать сотрудничество между странами НАТО и странами-партнерами предлагая платформу для дискуссий между экспертами НАТО и экспертами партнеров. И в итоге, группа ставит себе целью создать программу образования военного и гражданского руководства, которая занимается этими комплексными проблемами.

В этом специальном издании журнала «Взаимосвязи» представлен обзор некоторых из тем, которые по мнению Рабочей группы являются «новыми вызовами безопасности». Этот перечень может и будет дополняться с течением времени по мере того, как в международном сообществе будут развиваться технологические инновации и политические процессы.

Авторы пяти первых работ в этом издании представили свои мысли по данной проблематике в Рабочей группе по новым вызовам безопасности и вызвали интересные дискуссии в ходе разных семинаров, которые привели к публикации Консорциумом ПрМ определенного числа работ, посвященного политике и предпосылкам в этой сфере. Здесь все они рассматривают вопрос, почему лица, определяющие политику в сфере безопасности, должны быть озабочены этой конкретной проблемой, каковы фундаментальные технологические тенденции и их потенциальные последствия для определения политики в наших странах и в НАТО. Авторы, не состоящие в группе, дополняют эти рассуждения, фокусируясь на конкретных проблемах так называемой «гибридной войны» в контексте российско-украинского конфликта.

Сопредседатели благодарят всех авторов и постоянных сотрудников за адекватную и содержательную дискуссию по вопросам политики международной безопасности. 


\section{Об авторе}

С 2011 года доктор Детлеф Пул работает Старшим советником по вопросам стратегической коммуникации Помощника Генерального секретаря НАТО по новым вызовам безопасности, делегированным министерством обороны Германии. До этого, с 2008 по 2011, он был Помощником директора «Délégation aux Affaires Stratégiques» Управления планирования политики министерства обороны Франции. Перед этим, с 2002 по 2008, он работал в качестве заместителя декана «Колледжа исследований по вопросам международных отношений и безопасности» при Центре им. Джорджа К. Маршалла в Гармиш-Партенкирхене в тесном сотрудничестве с министерством обороны и Европейским командованием вооруженных сил США, а также с представителями Восточной Европы и Евразии. С 1998 по 2001 он был Директором по печати и информации и спикером министерства обороны Германии. До этого доктор Пул долгие годы работал корреспондентом по военным вопросам и политике безопасности в «Stuttgarter Zeitung» в Бонне и Штутгарте.

E-mail: detlef.puhl@gmx.net 